\title{
REPRESENTATION OF IDEOLOGICAL EDUCATION IN THE NUSANTARA FICTION
}

\author{
Rudi Umar Susanto ${ }^{1}$ \\ Universitas Nahdlatul Ulama Surabaya \\ Fifi Khoirul Fitriyah ${ }^{2}$ \\ Universitas Nahdlatul Ulama Surabaya \\ rudio@unusa.ac.id ${ }^{1}$ \\ Submit, 22-11-2019 Accepted, 30-12-2020 Publish, 30-12-2020
}

\begin{abstract}
The purpose of this research is to describe the Form of Ideology in Nusantara Folk Fiction Issued by the Ministry of Education and Culture in 2016. This study uses a qualitative interpretive approach with a parallel reading approach. The method is used to describe and interpret ideological representations in the 2016 Folk Archipelago Fiction published by the Ministry of Education and Culture in 2016. Data collection used in research is documentation technique, reading technique, and note taking technique. In this study produced two discussions, the form of ideology that can be used as an educational tool, and the ideological structure contained in the folklore of the archipelago. The forms contained are, among others, nationalist ideology and social ideology. In this connection, the two ideologies provide a foothold in this story. Moreover, nationalist values and social values that make a difference from other literary works. While for the ideological structure of this archipelago folklore, it is found that the ideological structure includes, Nationalists that lead to identity, and social which leads to social democracy.
\end{abstract}

Keywords: Children's Literature,Nusantara People's Fiction,Ideology Education.

\section{INTRODUCTION}

Literary works are a part of the scope of the reality of the humanity of the author of his existence.Literature as an idea that must be communicated and shared with others, ideology requiresamediain carrying outthiscommunication process, including literature in it.Then space turns into a tool because literature is understood as praxis and not ontological.Marxist customs, ideology as a culture that is arranged to be able to bring certain groups to have maximum control with minimal conflict potential.Ideology itself does not intend to pressure other groups but rather problems of dominant institutions in society capable of working through values, world conceptions and symbol systems in order to legitimize power. 
In Marx's ideas ideology is a superstructure while the socio-economic system that runs parallel is the base and literature is part of the superstructure. The ideology that exists in literature has a meaning in the form of literary interests with the ultimate goal of placing humans as objects as well as literary subjects in interpreting the times.Ideology also plays a role in the power of literature. Social, political and literary experience and history.

The urgency of this research is theoretically expected to be able to contribute to the development of ideological education at the elementary school level.The results of this study are practically expected to contribute ideas towards solving problems related to ideological education at the level of basic education.Furthermore, the results of this study are expected to be a reference for further researchers on ideological education in the fiction of the Indonesian archipelago.

Stendhal (in Damono, 1978) states in literature, politics is like the eruption of a pestol in the middle of a concert performance; it sounds lacking and tacky, but we can't help but pay attention to it.The novelist's statement was quoted by Irving Howe as the beginning of his introduction to the book which discusses the relationship between literature and politics.In this book Howe discusses great poet novels such as Stendhal, Dostoievski, Malraux, and Orwell; and this interesting study was preceded by an introduction which discussed the idea of a political novel.

Falah (2018) conduct research on the novel Ayat-Ayat Cinta (AAC) by Habiburrahman el Shirazy with ideological hegemony approach, the author's knowledge based on search on the internet, reference to the latest online journal (last 5 years), not found yet. Various related studies AAC most of them reviewed from the aspect of religiosity, da'wah and religious messages. This study aims to reveal ideological hegemony contained in the novel AAC. This literature study research, using the Gramsci hegemony approach. The research method used is descriptive analytic. The results showed Fahri's main character was constructed by the author with many positive attributes attached; handsome, smart, simple, obedient, and kind. These positive attributes and images make most female figures (Aisha, Maria, Nurul, Noura, Alicea) interested and admired Fahri, so Fahri also benefited and became a dominant class (hegemonic). Hegemony process these figures pan out, because one of them supported by religious ideology.

Research conducted by Rokhmansyah (2019) is to describe ideological formations and ideological negotiations that occur in Indra Tranggono's short story Tikus. In this study, the hegemony concept according to Antonio Gramsci was used. The ideology that appears in the text is calculated to show the ideological formation of the characters so that the dominant ideologies and ideologies that are negotiated can be identified. This research is a descriptive 
qualitative research with a sociological literature approach. The data analysis technique used content analysis techniques in the form of literary texts. The results showed that there were ideological formations in the text, namely militarism, bapakism, capitalism, and gotong royong. In the text, there is also a new common sense in the subaltern group after ideological negotiations between the dominant and subaltern groups. The short story also shows the weakening of the ideology of the dominant group so that the ideology resulting from the negotiations is lost and returns to the original ideology of the subaltern group.

Dwipayana, et.al (2018) study examines forms of feudalistic ideological hegemony and character resistance against them in literary works set against Balinese sociocultural. This research has a theoretical contribution to the development of science especially about sociological discourse in literature. This study uses a critical descriptive qualitative research design that moves from a functional approach to literary works with Balinese sociocultural background. The primary data sources in this study were the novels of Tarian Bumi (2007) by Oka Rusmini, Incest (2008) by I Wayan Artika, and short story Ketika Kentongan Dipukul di Bale Banjar (1969) by Rasta Sindhu. The study concludes that the feudalistic ideological hegemony in Balinese sociocultural literary works are represented by customary matters of adat and the caste system. The characters resistance against them are carried out in various ways ranging from being strong, independent, showing mimicry attitude; masculinity and sexual disorientation, and being reactionary.

Humanika (2011). this research bears two findings: (1) in the translating of the wordplays the translators applied five techniques, i.e.literal translation (71\%), wordplay-wordplay translation (18\%), compensation (6\%), editorial technique (2.5\%), and deletion (2.5), and (2) the domination of the foreignizing ideology in the process of decision making in the translation.

Handri (2020) based on the result of this study, there are four forms of ideology found in the novel, namely individualism ideology, socialism ideology, liberalism ideology, and fascism ideology. Ideological formations in the novel appear in four relationship, namely individualism between socialism, the relationship between individualism and liberalism, the relationship between liberalism between socialism and the relationship between liberalism and socialism. in each formation there was a dominant ideology. On the other hand, there was ideology that was dominated (subaltern position).

Arifin (2018) the results show that, first, the ideological structure in the Eyewitness short story includes external and internal material practice of the text. The external aspect of the text is the result of articulation of the domination of the New Order. For this reason, Eye Witnesses also did not escape the influence of Suharto's mobilization, but Seno and Eyewitnesses were able to oppose this 
policy. Second, the internal construction of the text, which was actually a space for meeting and negotiating existing ideologies. Eye Witnesses tried to show the totalitarian horror of the New Order. However, of course, in a repressive political space, criticism in the spirit of humanity, justice and freedom of opinion is transformed and wrapped in Eyewitness short stories with satirical and comedic characteristics, as well as expressing its horror.

Several relevant previous studies have similarities in terms of discussing their ideology. However, the writing that is being produced differs in terms of data sources and discussion.

\section{LITERATURE REVIEW}

In political novels, politics plays a major role and political background is the main background. In its most ideal form, political novels are novels that contain internal tension. To be considered a novel, it must contain depictions of human behavior and feelings; in addition he must absorb modern ideology. Novels deal with small feelings, passions, and emotions; but more than that he tried to capture concrete experiences. Ideology is something abstract in nature, and certainly will "disobey" if forced into the novel.

The beginning of the emergence of the idea of liberalism was explained by RamlanSubekti (in Rohaniah, 2015) that is, aristocrats alone are allowed to own land, these feudal groups also control the political and economic process, while the farmer is a land tenant owned by the rules, who must pay taxes and contribute labor for the patron.In the ideology of liberal-capitalism ideology creates the realization of a society that is free and able to regulate itself and develop creatively, innovatively, and independently by providing full protection of the rights of each individual in regulating his life.

Whereas the regulation of political life is based on the principles of democracy and the system of government generally adopted by the parliamentary system of government, although certain countries adopt a presidential system such as the United States and Indonesian.In social life the ownership of individual wealth of citizens is not restricted and social interaction is based on the values of freedom and independence of individuals and equality.

In some places in Europe, farmers are even allowed to move to other places as desired without the consent of the patron (nobleman).As a result, they are not the patron's personal property.Instead, the welfare of the cultivators should be borne by the patron. Rohaniah (2015) explained that liberalism grew in European society in the Middle Ages. When it is characterized by two characteristics, namely: First, members of the community are bound to one another in a complex and strong domination; and Second, the pattern of relationships in the system is static and difficult to change. 
Rohaniah (2015) explains that a new need is formed on the rules that are instituted in an institutionalized manner by the feudal groups. That helped the new economic group in spite of these difficulties, then came the liberal understanding. Liberalism was not created by an intellectual group that was driven by scientific unrest (curiosity and desire to seek new knowledge) and general artistic at that time.

In the end the idea of liberalism became the dominant political ideology in the Western world. Liberalism is a doctrine whose meaning is the spirit of individualism.Every individual is valued for his freedom in the economy, politics, law, culture in a country, which is packaged in terms of freedom, independence and equality. In this thinking a society that is the best (the best regime) is what allows individuals to develop their individual abilities to the fullest.

Democracy has been discussed for quite a long time, this is to provide a set of clear ideas about democracy that can be agreed upon by everyone. Rohaniah (2015) explains democracy is defined by the terms "the will of the people"; the source and purpose of "the common good" (the commond good), brought down by Schumpeter through what he calls "another theory of democracy," that is, "the democratic method," is an institutional procedure for achieving political decisions in which individuals gain power to make decisions through competitive struggle in order to obtain votes.

Democracy is more an arena of philosophers theorizing, and is not a political system that is truly adopted and practiced by the people. Even in this rare case, where a "democratic state" or a "republic" really exists, most people are not entitled to participate in political life.

CF Strong (in Rohaniah, 2015) explained that democracy is a form of government that is organized and organized based on the principles of popular sovereignty, political equality, consultation or dialogue with the people (political consultation), and based on majority.Democracy is also interpreted as a national political system based on citizen participation, majority rule, consultation and discussion, and the leader's responsibility for elections (Dalys M. Hill).In addition, democracy is a form of government whose power in making decisions for a country is legally determined, not according to groups or groups, but according to members of a community as a whole.

The term democracy is used to refer to the power of "the people" as opposed to "groups." The Greek word demos describes a large number, which is different from a small number.The word demos itself tends to show people as a whole. When the focus of democratic governance shifts to large-scale units such as the nation or state, the question that arises is: how can effective participation be realized if the number of citizens is too large and geographically too widespread. 
Nationalism is an ideology that is relatively old. This ideology has even begun to grow when humans begin to agree to determine the future of their lives.This agreement is what then causes people to start thinking there is a need for inter-community relations, so that human life becomes safe, peaceful, prosperous, without fear of interference from other communities. This fact then led to a conjecture, even the conception of Nationalism was born due to human natural needs.

Rohaniah (2015) explains the term Nationalism from the Latin natio, which means a nation united by birth.It can be said, nationalism is a view that considers the nation as an ideal form and political organization.The nation itself, understood as an azaz-reason, consists of two things: the people used to have to go through a history together; and the people must now have the will, the desire to live as one.Not type (race), not language, not religion, need equality, not national boundaries that make the "nation".And, the nation is a unity of temperament that occurs from the union of things that are lived by the people.

In Friedrich Hertz's view (in Rohaniah, 2015) the main and fundamental thing of nationalism is "national consiousness" or national consciousness. Therefore it can be said, nationalism is the formalization of national consciousness.Furthermore, it is this national awareness that raises the masses into social and political conditions. Nationalism is an understanding which believes that the highest loyalty of individuals must be handed over to the nation state.Nationalism as the origin of national consciousness contains ideals that encourage and stimulate a nation.

Socialism is a reaction to the industrial revolution and its aftermath - this teaching is a form of human disappointment at the oppression committed by humans (industrialists / capitalists) against other human beings (the proletariat / workers). The beginning of socialism that emerged in the first part of the 19th century was known as a socialist utopia. This socialism is based more on a humanitarian view, and believes in the perfection of human nature. Adherents of this understanding hope to create a socialist society that is aspired to with clarity and clarity of argument, not by means of violence and revolution.

Rohaniah (2015) explains the next development, social analysis of socialist understanding seems clearer. This understanding believes that human progress and justice are impeded by the institution of property rights over the means of production.The solution, according to this understanding is to limit or abolish private property rights (private proverty) and replace them with joint ownership of the means of production.In this way, the inevitable distribution of wealth from private ownership institutions under capitalism can be eliminated. Then in its development, this understanding of socialism became so strong-widely applied in Western European countries, because this ideological principle is so thick with the 
defense of one's fate-in short, socialism emphasizes its teachings on the collective ownership of the means of production.

Purnomo (2019) examines the views of the main characters in the novel A Bird Named Enza Dawn Meier's work on the American Dream: A Sociological Literary Approach (2009). This research produces a view of the American Dream in the novel A Bird Named Enza.The views of the American Dream are discussed according to the main characters in a varied but similar manner, namely having a strong desire to create a better life in Lemmon with the typical American Dream spirit, namely liberty, equality, and prosperity.

\section{RESEARCH METHOD}

This research is a research with a qualitative approach with literary criticism design focused on forms of ideology.This research utilizes reading and note taking techniques in data collection. Research data sources are three nusantara folklore. The book of folklore used is a book published in 2016 by the Language Development and Cultivation Agency.The three folklore in question is, Banterang Surati Creation M. Oktavia Vidiyanti, Si Dayang Rindu Creation Dian Anggraini, Joko Dolog Creation Dian Roemiati.

The three folklore is used as a source of data because the three short stories have similar themes raised, namely about the life of the Indonesian archipelago, in addition, the three folklore are published by the Language Development and Cultivation Agency.The data in this study are excerpts from the text of folklore containing ideological depictions experienced by the characters, as well as quotations that contain a picture of the impact of ideology that occurs in the lives of the characters. The three folklore used in this study can be as an illustration for teaching materials used at the elementary school level and do not rule out the emergence of ideologies in it.

The steps in this study are described as follows. First, reading folklore that is used as an object of research.The reading is done in two stages. The first stage is heuristic reading, which is reading the text of folklore repeatedly to get an initial understanding.

Heuristic reading is also used as a preliminary observation step. The second stage of reading hermeneutics, which is reading the text in depth in order to get a more detailed understanding of the contents of the text of folklore.Second, record all the data needed and related to the indicators of each problem statement. Quotations obtained are then recorded on the data card in accordance with the indicator.Third, make tabulation or classification of data that has been collected in accordance with the indicators. Fourth, analyzing data in accordance with the formulation of the problems that have been disclosed and to achieve research objectives.Data analysis was carried out by utilizing the 
theories used as a research foundation. Then the descriptive analysis of data analysis is performed. Fifth, draw conclusions from the analysis that has been done.

\section{FINDING}

\section{Form of Educational Ideology in the Folklore of the Nusantara}

In this discussion, the folklore of the nusantara has an ideology that can be used as learning material for children.Ideology has an important role in determining the outlook on life of a society. Every citizen in this part of the world has their own view of life that has been adapted to the culture and character of its citizens. The ideology in Indonesian contains values that can make the followers become something different, namely by way of thinking and the workings of these ideologies.

As in the folklore of this nusantara, the narrative contains elements of ideology that can be used as a means of education for children in Indonesia. The data is as follows:

Answering Ki Bayi Cilik, "You will not be far from us. Right now, whatever orders the WayangSewu will obey, including if I have to sacrifice my soul. Even if you die in the middle of a tiger, I will ask to be buried together. "Dayang Rindu asked Ki Bayi Cilik not to be sad after she went to Palembang. He asked him to be loyal to the Cape of Iran. "Let me go to Palembang so that doomsday will not occur here," said Dayang Rindu. (Anggraini, 2016:)

Based on these data, an ideological education that has penetrated someone's heart will make him a person who is obedient, loyal, and willing to sacrifice.Because his soul was indoctrinated to carry out all the tasks given. This can be seen in the soul of the figure of Ki Bayi Cilik, he is ready to sacrifice his soul for the benefit of his country.

If drawn to current conditions, a stream of globalization causes increasingly fading values of the nation's character in society, especially in children. With the exchange of national culture, many foreign cultures entered that eventually damaged the nation's character values.

Children prefer foreign culture to the original culture of this nation. This is evidenced by the feeling of being proud to use foreign products.In addition, the fading of national values can be proven by the increasing number of phenomena, even the elimination of efforts to instill national values in schools.In addition to these data, there are also other data that show the value of nationalist ideology in this folklore. The data is as follows: 
Despite being asked by SingaRalang not to go down to fight, KeriyoCarang remained in her decision. He was not afraid at all in facing the Palembang group. In fact, he asked the Ralang Lion to remain in the palace. "Right now you are the only successor to the Cape of Iran. Let us face them, "said KeriyoCarang. (Anggraini, 2016)

Based on these data shows the nationalist spirit shown by the figure KeriyoCarang in protecting his country. The nationalist ideology can be used as a means for ideological education, especially nationalist ideology which is aimed at children of the nation's next generation.

The young generation as the holder of the nation's leadership relay has not yet reflected the expected educational ideals. This problem is a fact that should not be ignored given the importance of the attitude of Nationalism in advancing the Indonesian State.When the government is so aggressively conveying about the education of national values or nationalism, the fostering of the education of national values through this educational channel is felt to be on time, on function, and on target.

Related to the inculcation of national values in the current global era, one of the formal institutions that is responsible is the education unit. In addition to these data, there are other data in other folklore. The data is as follows:

"Every day I go to this forest. I really love the forest and everything because since childhood I have been friends with life in the forest, "explained JokoJumput to JakaTaruna (Roesmiati, 2016)

Based on these data, nationalist ideology does not have to be aimed at the love of the state or regional like. However, even nationalist ideology must be directed to everything that exists in this world. As long as everything is positive.

One form of ideology is shown by the character JokoJumput who loves the forest and its contents. This attitude is a form of ideology that must be possessed by the whole community. The environment is a circumstance that affects the development and behavior of living things. Everything that exists around humans that influences the development of human life both directly and indirectly is also part of the environment.

Besides national ideology, in the folklore, there is a social ideology that leads to social democracy. This ideology is a manifestation of social behavior that always respects the interests of others.

Prince Situbondo does look physically handsome, but in fact he has a brangasanbehavior, or arbitrary, and easily offended. This trait is derived from his father, Cakraningrat I. This is what makes Duke Jayengrana less sympathetic to him, as is DewiPurbawati. They were confused thinking 
about how to reject the Situbondo proposal. They did not want to offend Cakraningrat I because of the rejection of the proposal. They also deliberated to think of a subtle way to refuse Situbondo's request.(Roesmiati, 2016)

Based on these data, forms of thought that always protect the feelings of others are outlined in the narrative. The nature of Duke Jayagrana who does not want to make others hurt his heart he always holds, both to ordinary people and to people. This is a form of positive character that must be emulated by all elements of society.Because the emergence of untrue news, usually comes from a form of feeling hurt by certain parties. Positive attitudes can be developed through understanding, one from an ideological point of view. In addition to these data, there can also be data in BanterangSuratri Folklore. The data is as follows:

After becoming a wife, Surati has told Banterang a lot. He told me that he was actually the princess of the Klungkung Kingdom. At that time, Banterang was shocked too. However, in the end he was happy when he was sure that his marriage to Surati actually strengthened the relationship between Blambangan and Klungkung..........(Vidiyanti, 2016)

Based on these data, the ideology of the Surati figure is a socialist ideology focused on social democracy. This can be seen in his attitude that wants to strengthen between Blambangan and Klungkung.Indeed, it cannot be denied if every regional leader sometimes has a conflict with the regional leader, both openly or secretly. In addition to these data, there are other data that show the social ideology contained in the folklore narrative. As for the data as follows:

"You're right, Aki. Previously, Rama could not completely win the war. However, for the sake of my good intentions, hopefully the great gods are willing to side with Blambangan so that this war will soon be over."

"Hope so, Duli Your Honor. There is no need for more war, no need for murder.". (Vidiyanti, 2016)

Based on these data, it shows social attitudes in establishing brotherhood, and there is no division through war.Relations between nations as a system in the international community have shown many separate units in certain situations and conditions, but on the other hand is a state of mutual influence of the forces formed from each unit and indeed from the beginning wanted the existence of the desire to show the hegemony of his strength. 


\section{Educational Structure of Ideology in the Folklore of the Nusantara}

Education is considered as a preventive alternative because education builds a new generation of a better nation. As a preventive alternative, education is expected to develop the quality of the nation's young generation in various aspects that can reduce and reduce the causes of various ideological problems. In this folklore the nusantara has an ideological structure that can be used as an educational tool for the nation's next generation children. The structure is as follows:

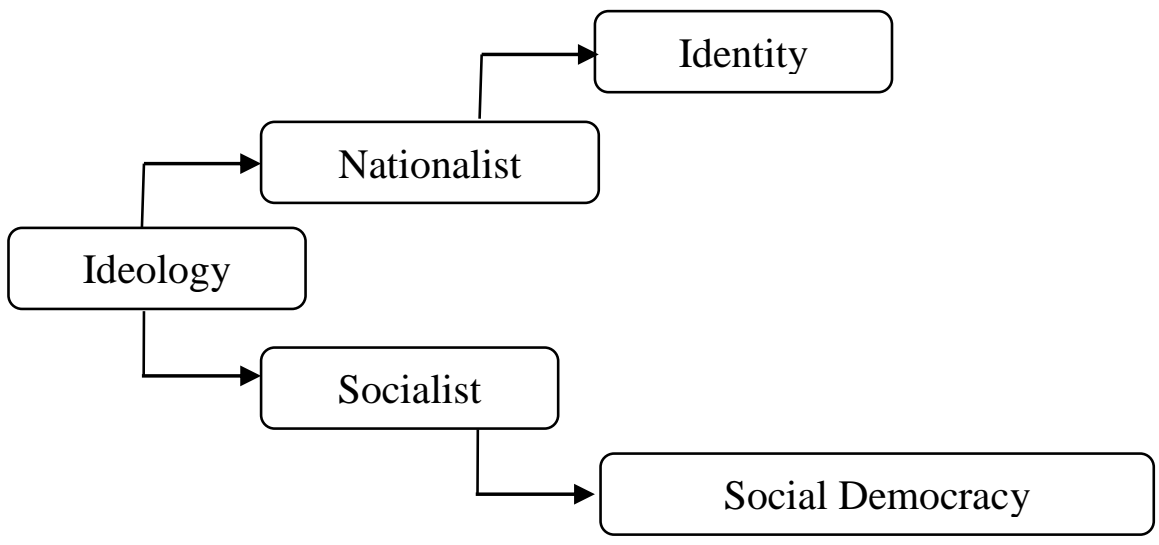

Chart 1: Ideological Structure in the Folklore of the Nusantara

Based on the above plot, in the folklore of the nusantara, explaining that ideology is an idea, belief and belief that is systematic in accordance with the direction and goals to be achieved in life.Ideology has become a precipitate of understanding that is used as the basis of one's thoughts and actions.

In these ideologies, each has its own direction, two of which are national ideologies that lead to the issue of identity, and socialist ideology that leads to the idea of social democracy. Nationalist ideology is a form of the idea of unity or character that binds the soul of locality, national awareness, and a feeling of belonging together. This makes an identity emerge.

In the folklore the nusantara shows the identities of the figures to inform the nationalist ideology that they hold. Speaking of nationalists, cannot be separated with the term nation. The word Nation comes from the Latin natio, which was developed from the word nascor (I was born), so at first the nation (nation) was interpreted as "a group of people who were born in the same area" (this group of people born the same place). The word 'nationalism' according to Abbe Barruel for the first time was used in Germany in the 15th century, which was intended for students who came from the same region or shared the same language, so that they (on new campuses and new areas) continued to show their love towards their national origin. 


\section{DISCUSSION}

The research results described cover: a) the form of ideological education in the folklore of the nusantara; b) the structure of ideological education in the folklore of the nusantara. As specifically as follows:The two ideologies of Russian/ Soviet Union communism differed in their implementation strategies after communism was successfully entrenched in the system of a state or a nation. However, the basic principle regarding the existence of the state remains the same, namely that state power must remain centralized (centralized). The state has large powers as controllers in the fields of government, politics, economics, and law. But in this ideology private ownership is allowed within certain limits. There is a form of educational ideology in the folklore of the archipelago that represents the identity that exists in Indonesia through narrative. These ideologies can be a support for achievement in maintaining the continuity of culture.

This research produces ideological forms and structures that exist in the folklore of the archipelago published by the Ministry of Education and Culture of the Republic of Indonesia. The ideology is used as a means of education for children to provide insights that can enter the minds of children.

The ideology used as a means of education is nationalist ideology and socialist ideology. In terms of nationalist ideology, this is a form of identification of an understanding of the condition and situation of a person in a region or country. Meanwhile, socialist ideology is a manifestation of conditions in society that all elements need to know and anticipate.

The existence of ideological information contained in children's reading books, especially the folklore of the archipelago, enables Indonesian children to know which aspects can be applied or which should be left out.

Nationalism was initially related to the love of a group of people in their original nation, language and area of origin. Such love today is called the spirit of patriotism. So in the beginning nationalism and patriotism had the same meaning. Understanding nationalism as an ideological movement to achieve and maintain autonomy, cohesion and individuality for a particular social group that is recognized by some of its members to form or determine a true or potential nation.

Meanwhile, socialist ideology is the idea of togetherness in a community to provide mutual benefits.This ideology has a sense of concern, sympathy and empathy between individuals for other individuals regardless of status. View of life and certain social teachings. In this folklore, the form of socialist ideology is directed towards social democation.

Social democracy is a political, social and economic ideology that supports the intertwining of social, cultural and economic elements. This is to encourage social compatibility within the framework of political entities. The protocols and norms used to achieve this involve a commitment to representative and 
participatory democracy, policies to redistribute income and economic regulation in the public interest and provision of social welfare.

\section{CONCLUSIONS}

This research resulted in the form and structure of ideology in the folklore of the nusantara published by the Language Development and Cultivation Agency. The ideology is used as an educational tool for children to provide insights that can enter the minds of children.The ideologies used as educational facilities are nationalist ideology and socialist ideology. In relation to nationalist ideology, this is a form of identity recognition for understanding the conditions and situations of someone in a region or country. While socialist ideology is a form of manifestation of conditions in society that need to be known and anticipated by all elements.

\section{REFERENCES}

Anggraini, D. (2016). Si Dayang Rindu: Folk Story from Lampung. Jakarta: Language Development and Cultivation Agency.

Arifin. (2018). Ideologi (Dan) Estetika Seno Gumira Ajidarma: Saksi Mata dalam Ruang Perjumpaan Ideologis. 15(2). DOI: https://doi.org/10.15575/altsaqafa.v15i2.3825

Damono, S., D. (1978). Literature, Politics, Ideology in Sociology of Literature: An Introduction. Jakarta: Center for Language Development and Development.

Dwipayana, I.,K.,A \& Artajaya, G.,S. (2018). Hegemoni Ideologi Feodalistis dalam Karya Sastra Berlatar Sosiokultural Bali. https://ocs.unud.ac.id/index.php/kajianbali/article/view/43216

Falah, (2018).Hegemoni Ideologi dalam Novel Ayat-Ayat Cinta Karya Habiburrahman el Shirazy (Kajian Hegemoni Gramsci)," Nusa: Jurnal Ilmu Bahasa dan Sastra, 13(3) 351-360, Aug. 2018. https://doi.org/10.14710/nusa.13.3.351-360

Handri, S. (2020) Ideologi-Ideologi dalam Novel I Promise You karya Karine. https://repository.stkippacitan.ac.id/id/eprint/276/

Humanika. (2011). Ideologi Penerjemahan Wordplay Dalam Alice's Adventures In Wonderland Ke Dalam Bahasa Indonesia. 39(2). DOI: https://doi.org/10.26499/wdprw.v39i2.34

Purnomo, A. (2009). Pandangan Para Tokoh Utama dalam Novel A Bird Named EnzaKarya Dawn Meier MengenaiAmerican Dream: Sebuah Pendekatan Sosiologi Sastra. Tesis Universitas Diponegoro. Semarang: Tidak diterbitkan.

Rohaniah, Y., \& Efriza. (2015). Introduction to Politics. Malang: Intrans Publishing. 
Rokhmansyah, A. (2019).Formasi dan Negosiasi Ideologi dalam Cerpen Tikus Karya Indra Tranggono Berdasarkan Perspektif Hegemoni Gramsci. 15(2). Roesmiati, D. (2016). Joko Dolog: Folk Story from East Java. Jakarta: Language Development and Cultivation Agency.

Vidiyanti, M. O. (2016). Banterang Surati: Folk Story from East Java. Jakarta: Language Development and Cultivation Agency. 